Article

\title{
Inactivation of Opportunistic Pathogens Acinetobacter baumannii and Stenotrophomonas maltophilia by Antimicrobial Photodynamic Therapy
}

\author{
Irina Buchovec ${ }^{1, *}$, Laurita Klimkaitè $^{2}$, Edita Sužiedèliené $^{2}$ and Saulius Bagdonas ${ }^{3}$ \\ 1 Institute of Photonics and Nanotechnology, Faculty of Physics, Vilnius University, LT-10257 Vilnius, Lithuania \\ 2 Institute of Biosciences, Life Sciences Center, Vilnius University, LT-10257 Vilnius, Lithuania; \\ laurita.klimkaite@kc.vu.lt (L.K.); edita.suziedeliene@cr.vu.lt (E.S.) \\ 3 Laser Research Center, Faculty of Physics, Vilnius University, LT-10257 Vilnius, Lithuania; \\ saulius.bagdonas@ff.vu.lt \\ * Correspondence: irina.buchovec@ff.vu.lt
}

check for updates

Citation: Buchovec, I.; Klimkaitè, L.; Sužiedèlienè, E.; Bagdonas, S. Inactivation of Opportunistic Pathogens Acinetobacter baumannii and Stenotrophomonas maltophilia by Antimicrobial Photodynamic

Therapy. Microorganisms 2022, 10, 506 https://doi.org/10.3390/ microorganisms10030506

Academic Editor: Adelaide Almeida

Received: 28 January 2022

Accepted: 23 February 2022

Published: 25 February 2022

Publisher's Note: MDPI stays neutral with regard to jurisdictional claims in published maps and institutional affiliations.

Copyright: (c) 2022 by the authors. Licensee MDPI, Basel, Switzerland. This article is an open access article distributed under the terms and conditions of the Creative Commons Attribution (CC BY) license (https:// creativecommons.org/licenses/by/ $4.0 /)$.

\begin{abstract}
Acinetobacter baumannii and Stenotrophomonas maltophilia are opportunistic pathogens causing hospital infections with limited treatment options due to bacterial multidrug resistance. Here, we report that antimicrobial photodynamic therapy (aPDT) based on the natural photosensitizers riboflavin and chlorophyllin inactivates A. baumannii and S. maltophilia. The riboflavin and chlorophyllin photostability experiments assessed the photomodifications of photosensitizers under the conditions subsequently used to inactivate A. baumannii and S. maltophilia. A. baumannii planktonic cells were more sensitive to riboflavin-aPDT, while biofilm bacteria were more efficiently inactivated by chlorophyllin-aPDT. S. maltophilia planktonic and biofilm cells were more susceptible to chlorophyllin-aPDT compared to riboflavin-aPDT. The results suggest that riboflavin- and chlorophyllin-aPDT can be considered as a potential antimicrobial treatment for A. baumannii and S. maltophilia inactivation.
\end{abstract}

Keywords: Acinetobacter baumannii; Stenotrophomonas maltophilia; photodynamic therapy; biofilms; natural photosensitizers; riboflavin; chlorophyllin; photostability

\section{Introduction}

Infections caused by antibiotic-resistant bacteria are a global problem urgently requiring new antibacterial agents or alternative antibacterial strategies [1]. During the last decade, the important clinical concern worldwide became nosocomial infections caused by Gram-negative opportunistic pathogens resistant to most clinically used antibiotics [2,3]. Opportunistic infections are hazardous to patients with compromised immunity, and are characterized by high morbidity and mortality [4]. The bacterium Acinetobacter baumannii is among the top infection agents for which new antimicrobial therapies are needed [5]. Genome plasticity and horizontal gene transfer enable successful $A$. baumannii adaptation to the clinical environment, the development of antibiotic resistance and virulence [6]. The prevalence of carbapenem-resistant $A$. baumannii in Europe reached $80 \%[7,8]$, creating the challenge of addressing these pathogen infections. Another newly emerging Gram-negative opportunistic pathogen causing serious concern is Stenotrophomonas maltophilia $[9,10]$. Although this bacterium is commonly found in nature, it also becomes dangerous to patients with deficient immunity [11,12]. S. maltophilia exhibits numerous virulence factors [13], as well as resistance to multiple antimicrobial agents [14]. Susceptibility against trimethoprim/sulfamethoxazole, the first-choice treatment for S. maltophilia infections, generally remains high (varying from 79 to $96 \%$ ). However, mortality rates for patients with resistant S. maltophilia infections can range from 14 to $69 \%$ [15].

Among the important virulence features responsible for pathogen survival and spread in a hospital environment is their ability to form biofilms on abiotic (medical equipment) 
and biotic (tissues and cells of the host) surfaces [16]. Bacteria in biofilm structures are surrounded by an extracellular matrix consisting of polysaccharides, DNA and proteins. Therefore, biofilms are significantly more resistant to antibiotic treatment, disinfectants, physical stress and host immunity [17]. Clinical A. baumannii and S. maltophilia isolates are characterized by their strong ability to form biofilms $[13,18]$. Mechanical, chemical and physical methods are used for biofilm control, but they all have limitations. Therefore, there is a need for more efficient approaches to biofilm inactivation [19].

Antimicrobial photodynamic therapy (aPDT) is a modern biophotonic technology which can be used as a viable alternative for inactivating antibiotic-resistant pathogens [20]. aPDT is based on the interaction of a photosensitizer (PS), molecular oxygen and low doses of light applied at suitable spectral region to match the PS absorption peak [21,22]. Usually, after light excitation, the triplet-state of PS interacts with molecular oxygen, electron donors or electron acceptors, and can produce reactive oxygen species (ROS), thereby triggering photo-oxidative reactions which initiate various types of cellular damage and can destroy bacterial cells [23]. The efficacy of aPDT depends on many factors, but most significantly on the photophysical properties of the used PS. PSs can be divided into several main groups based on their structure and origin - synthetic dyes, nanostructures, and natural PSs [24]. Natural PSs, such as riboflavin (RF) and chlorophyllin (Chl), are safe and environmentally sustainable [22]. However, data on natural PS-based aPDT perspectives in the control of emerging multidrug resistant hospital infection agents and their biofilms remain scarce. For A. baumannii aPDT inactivation, only a few natural PSs [25-28] have been analyzed, although none of these studies addressed biofilm inactivation. Furthermore, no research has been performed on S. maltophilia aPDT inactivation, neither with natural nor with other PSs. In this study we aim to investigate whether natural PS riboflavin- and chlorophyllinbased aPDT can efficiently inactivate antibiotic-resistant $A$. baumannii and S. maltophilia bacteria and their biofilms.

\section{Materials and Methods}

\subsection{Solutions}

For the aPDT experiments, a stock solution of riboflavin (RF) $(\mathrm{MW}=376.36 \mathrm{~g} / \mathrm{mol}$, Sigma-Aldrich, St. Louis, MO, USA) ( $0.11 \mathrm{mM}, \mathrm{pH}$ 6.8) was prepared by stirring RF in distilled water at $50{ }^{\circ} \mathrm{C}$ for $4 \mathrm{~h}$ [29]. The solution was sterilized by a $0.22 \mu \mathrm{m}$ syringe filter and stored at $4{ }^{\circ} \mathrm{C}$ in the dark before use. A stock solution of non-copperized chlorophyllin sodium salt (Chl) (MW $=684.9 \mathrm{~g} / \mathrm{mol}$, Carl Roth, Karlsruhe, Germany) $(1.5 \mathrm{mM}, \mathrm{pH} 7.2)$ was prepared by pipetting $\mathrm{Chl}$ at room temperature for about $60 \mathrm{~s}$ without any heating or shaking [30]. All working solutions were freshly prepared by diluting them with $0.01 \mathrm{M}$ PBS buffer on the day of use.

\subsection{Bacterial Strains and Growth Conditions}

A. baumannii clinical isolate II-a [31] and S. maltophilia clinical isolate SM3 [32] were chosen for the aPDT approach study. In all experiments, A. baumannii was grown in LuriaBertani (LB) and S. maltophilia was grown in Tryptone soya broth (TSB) medium; both isolates were grown at $37^{\circ} \mathrm{C}$.

\subsection{Light Source for aPDT}

The LED-based light source for the photoinactivation of bacteria was constructed at the Institute of Photonics and Nanotechnology of Vilnius University (Figure 1). It consisted of an illumination chamber and a supply unit. The illumination chamber size was optimized for even illumination of microplates ( 96 wells) or Petri dishes by the light of a selectable predefined spectrum. 


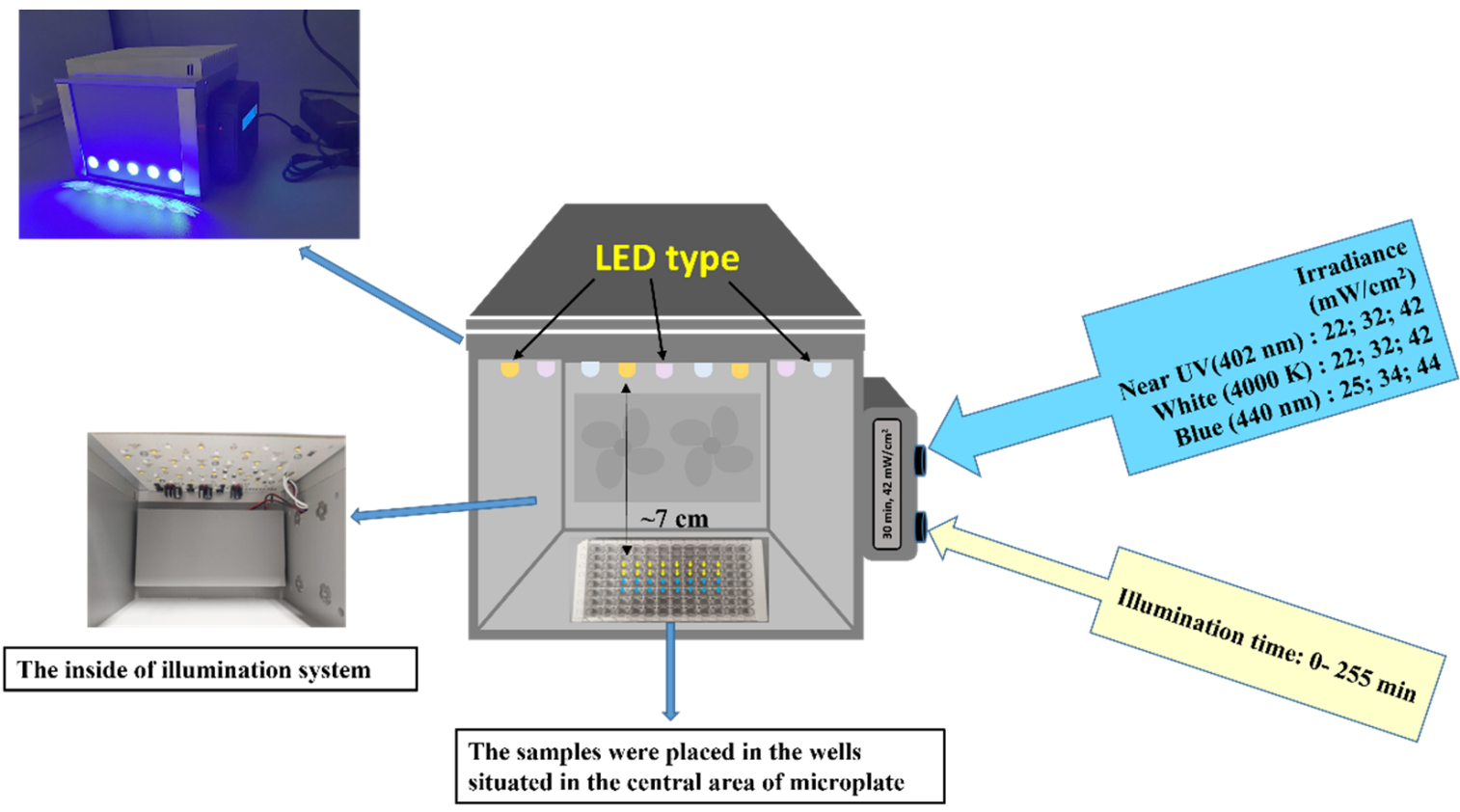

Figure 1. The illumination system used in the aPDT experiments.

The illumination routines and timing were controlled by an integrated microcontroller unit (MCU), which comprises three types of LEDs emitting at the near-UV (402 nm), blue $(440 \mathrm{~nm})$, and white $(4000 \mathrm{~K})$ spectral regions. Two types of LEDs (402 $\mathrm{nm}$ and $440 \mathrm{~nm}$ ) with emission peaks near the maximum absorption of RF and Chl were used (Figure 2).

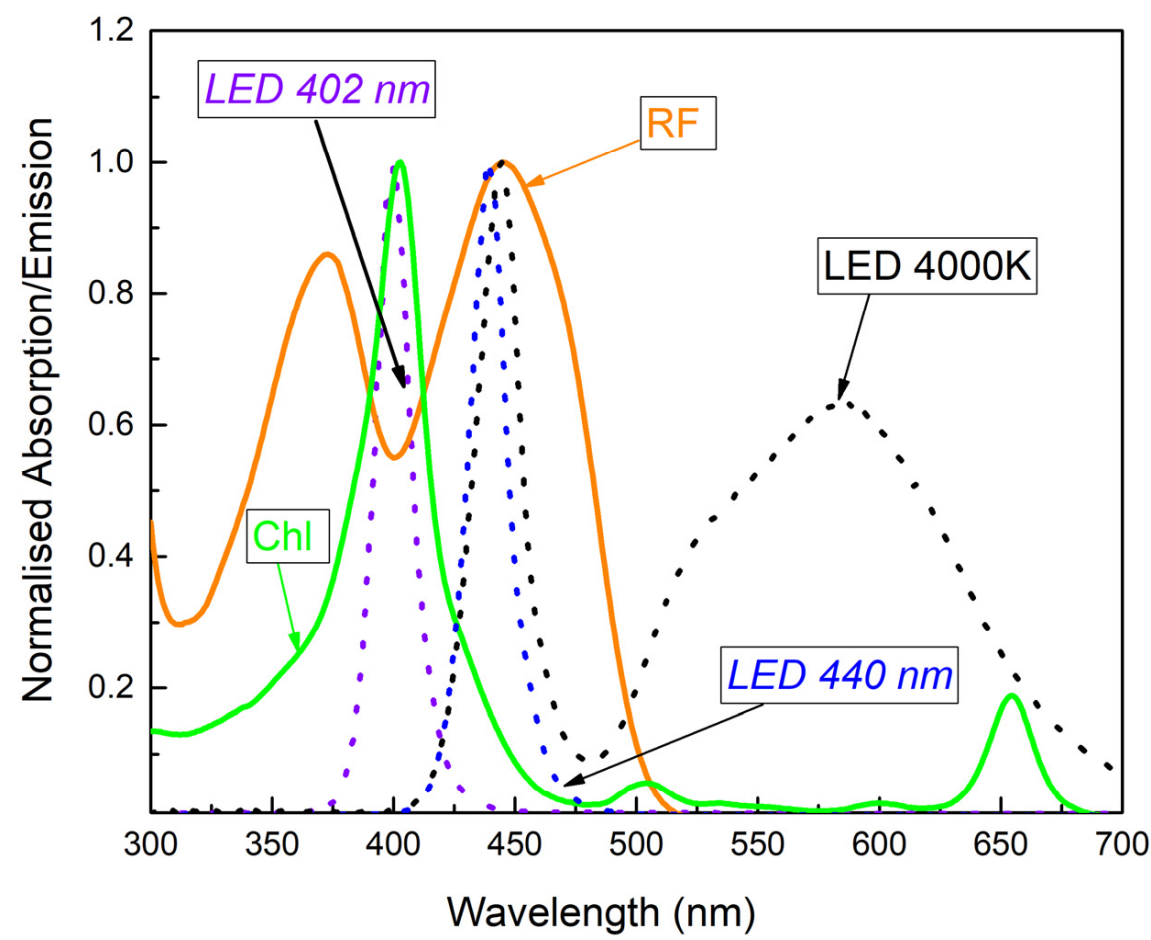

Figure 2. Normalized absorption spectra of RF and Chl in 0.01 M PBS, as well as emission spectra of the selected $402 \mathrm{~nm}$ and $440 \mathrm{~nm}$ LED. LED $4000 \mathrm{~K}$ was not used in the study.

The light irradiance at the surface of the samples $(7 \mathrm{~cm}$ from the light source) reached 25,42 and $-4 \mathrm{~mW} / \mathrm{cm}^{2}$. A cooling system was integrated into the light source to dissipate heat and minimize the heating of the sample. The illumination dose $\left(\mathrm{J} / \mathrm{cm}^{2}\right)$ was calculated 
as irradiance $\left(\mathrm{mW} / \mathrm{cm}^{2}\right)$ multiplied by illumination time (s). The illumination doses used in experiments are shown in Table 1.

Table 1. Illumination doses used in experiments.

\begin{tabular}{|c|c|c|c|}
\hline \multirow[b]{2}{*}{ Time (min) } & \multicolumn{3}{|c|}{ Illumination Dose $\left(\mathrm{J} / \mathrm{cm}^{2}\right)$} \\
\hline & $\begin{array}{c}440 \mathrm{~nm} \\
\text { Irradiance } \\
25 \mathrm{~mW} / \mathrm{cm}^{2}\end{array}$ & $\begin{array}{c}402 \mathrm{~nm} \\
\text { Irradiance } \\
42 \mathrm{~mW} / \mathrm{cm}^{2}\end{array}$ & $\begin{array}{c}440 \mathrm{~nm} \\
\text { Irradiance } \\
44 \mathrm{~mW} / \mathrm{cm}^{2}\end{array}$ \\
\hline 0.25 & - & 0.63 & 0.66 \\
\hline 0.5 & - & 1.26 & 1.32 \\
\hline 1 & - & 2.52 & 2.64 \\
\hline 2 & - & 5.04 & 5.28 \\
\hline 3 & - & 7.56 & 7.92 \\
\hline 5 & - & 12.6 & - \\
\hline 10 & 15 & 25.2 & 26.4 \\
\hline 15 & - & 37.8 & 39.6 \\
\hline 20 & 30 & 50.4 & 52.8 \\
\hline 30 & 45 & 75.6 & 79.8 \\
\hline 60 & - & 151.2 & 158.4 \\
\hline
\end{tabular}

\subsection{Spectrophotometric Assessment}

The absorption spectra of the PSs solutions were recorded by means of a LAMBDA 950 UV-VIS-NIR spectrophotometer in the spectral region of 300-600 nm and 300-700 nm (for RF and Chl, respectively). Polymethyl methacrylate cuvettes of $1 \mathrm{~cm}$ were used for the measurements. All measurements were performed at $20 \pm 2{ }^{\circ} \mathrm{C}$. The solutions of $0.011 \mathrm{mM}$ $\mathrm{RF}$ (pH 7.4) and 0.015 mM Chl (pH 7.4) in 0.01 M PBS were illuminated with an LED-based light source for analysis of the photostability of the PSs. The changes in the absorption spectra of RF and Chl were investigated after LED illumination at $440 \mathrm{~nm}$ or $402 \mathrm{~nm}$. For this purpose, $200 \mu \mathrm{L}$ of the PSs were transferred to microplates (16 wells) and exposed to 42 and $44 \mathrm{~mW} / \mathrm{cm}^{2}$ irradiance. After each illumination dose was applied separately, the samples $(3 \mathrm{~mL})$ were collected into cuvettes and used for spectrophotometric measurements.

\subsection{Effect of aPDT on the A. baumannii and S. maltophilia Planktonic Cells}

The overnight cultures of $A$. baumannii and S. maltophilia were diluted 1000 times with a fresh medium and grown until reaching OD600 $=0.65$ for $A$. baumannii and OD600 $=0.45$ for $S$. maltophilia $\left(1-5 \times 10^{8}\right.$ colony forming units $\left.(\mathrm{CFU}) / \mathrm{mL}\right)$. Then, the bacteria were harvested by centrifugation $\left(10 \mathrm{~min}, 6^{\circ} \mathrm{C}, 7000 \times \mathrm{g}\right)$, suspended in the $0.01 \mathrm{M}$ PBS and immediately used for the riboflavin-based aPDT (RF-aPDT) and chlorophyllin-based aPDT (Chl-aPDT) experiments using LED illumination at $440 \mathrm{~nm}$ and $402 \mathrm{~nm}$, respectively. The bacterial cultures $\left(\sim 1 \times 10^{7} \mathrm{CFU} / \mathrm{mL}\right)$ were suspended with $0.011 \mathrm{mM}$ RF or $0.015 \mathrm{mM} \mathrm{Chl}$ in the dark at room temperature. For the photoinactivation, $200 \mu \mathrm{L}$ of the samples (control and with PSs) were placed into sterile, flat-bottom wells and exposed to LED light for different periods (Table 1 ). Light and dark controls of A. baumannii and S. maltophilia were also included, and some were incubated in the dark $(0 \div 30 \mathrm{~min})$ while the other samples were irradiated. The antibacterial effects of aPDT were evaluated by the microdilution method [33], where $10 \mu \mathrm{L}$ of appropriate dilutions of bacterial test culture after treatment was applied to a separate LB plate and incubated at $37^{\circ} \mathrm{C}$ for $24 \mathrm{~h}$. After incubation, the colonies were counted and an average value was calculated for every point (from 3 to 6 experiments) and expressed as $\log$ of $\mathrm{CFU} / \mathrm{mL}$.

\subsection{Inactivation of A. baumannii and S. maltophilia Biofilms with aPDT}

For biofilm formation, overnight A. baumannii II-a and S. maltophilia SM3 cultures were diluted 1000 times and $100 \mu \mathrm{L}$ aliquots $\left(1-5 \times 10^{7} \mathrm{CFU} / \mathrm{mL}\right)$ were transferred to sterile 96 -well microtiter polystyrene plates and incubated at $37^{\circ} \mathrm{C}$ for $24 \mathrm{~h}$. After the 
incubation, the medium was discarded and the wells were gently washed three times with sterile PBS (pH 7.4). For aPDT, biofilm wells were filled with $200 \mu \mathrm{L}$ of $0.11 \mathrm{mM}$ $\mathrm{RF}$ or $0.15 \mathrm{mM}$ Chl solutions. The control wells contained $200 \mu \mathrm{L}$ of PBS. To maximize PS adsorption to the biofilms, the plates were incubated in the dark at room temperature (aprox. $25^{\circ} \mathrm{C}$ ) for $60 \mathrm{~min}$. When illumination was not applied, the biofilms were detached immediately after incubation. For aPDT of biofilms with RF or Chl as well as in the case of the control, the wells were illuminated for $60 \mathrm{~min}$ with $440 \mathrm{~nm}$ LEDs $\left(44 \mathrm{~mW} / \mathrm{cm}^{2}\right)$ or $402 \mathrm{~nm}$ LEDs $\left(42 \mathrm{~mW} / \mathrm{cm}^{2}\right.$ ) appropriate for RF and Chl, respectively. After illumination, bacterial biofilms were mechanically detached from the wells and vigorously vortexed. aPDT efficacy against A. baumannii and S. maltophilia biofilms was evaluated by determining the CFU on LB plates (microdrop method), as described previously [33].

\subsection{Statistical Analysis}

The aPDT inactivation experiments were repeated at least 3-6 times. A standard deviation was estimated for every experimental point, as marked in the figure as an error bar. Data were processed with Origin Pro 9.1 software (OriginLab Corporation, Northampton, MA, USA) and were statistically analyzed using One-way Analysis of Variance (ANOVA). The post hoc Bonferroni test was used for the comparison between the experimental groups and the control group. The level of significance was set at $p<0.05$.

\section{Results}

\subsection{Photostability of Riboflavin and Chlorophyllin}

Almost all PSs are degraded during the light illumination through oxygen mediated processes. Therefore, it is important to assess PSs photostability. Fast photobleaching can be a disadvantage in aPDT, as the PS cannot form enough ROS to kill bacteria. To assess photostability under different illumination doses, we analyzed the changes in the absorption characteristics of riboflavin (RF) and chlorophyllin (Chl), after illumination with $402 \mathrm{~nm}$ or $440 \mathrm{~nm}$ LED light.

Figure 3A shows the spectra recorded after illumination of $0.015 \mathrm{mM} \mathrm{Chl}$ solution in PBS at $42 \mathrm{~mW} / \mathrm{cm}^{2}$ for different time periods $\left(0-30 \mathrm{~min}\right.$, which corresponds to $0-75.6 \mathrm{~J} / \mathrm{cm}^{2}$ illumination doses). The absorption peak of $\mathrm{Chl}$ at $403 \mathrm{~nm}$ rapidly decreased to about $20 \%$ after illumination for $3 \mathrm{~min}\left(7.56 \mathrm{~J} / \mathrm{cm}^{2}\right)$ and reached $12 \%$ of its magnitude after $10 \mathrm{~min}\left(25.2 \mathrm{~J} / \mathrm{cm}^{2}\right)$. The illumination at $440 \mathrm{~nm}$ diminished the peak magnitude to the same extent only after $20-30 \mathrm{~min}\left(79.8 \mathrm{~J} / \mathrm{cm}^{2}\right)$, which was consistent with the reduced absorbance intensity of the $\mathrm{Chl}$ in this spectral region (Figure 3B).
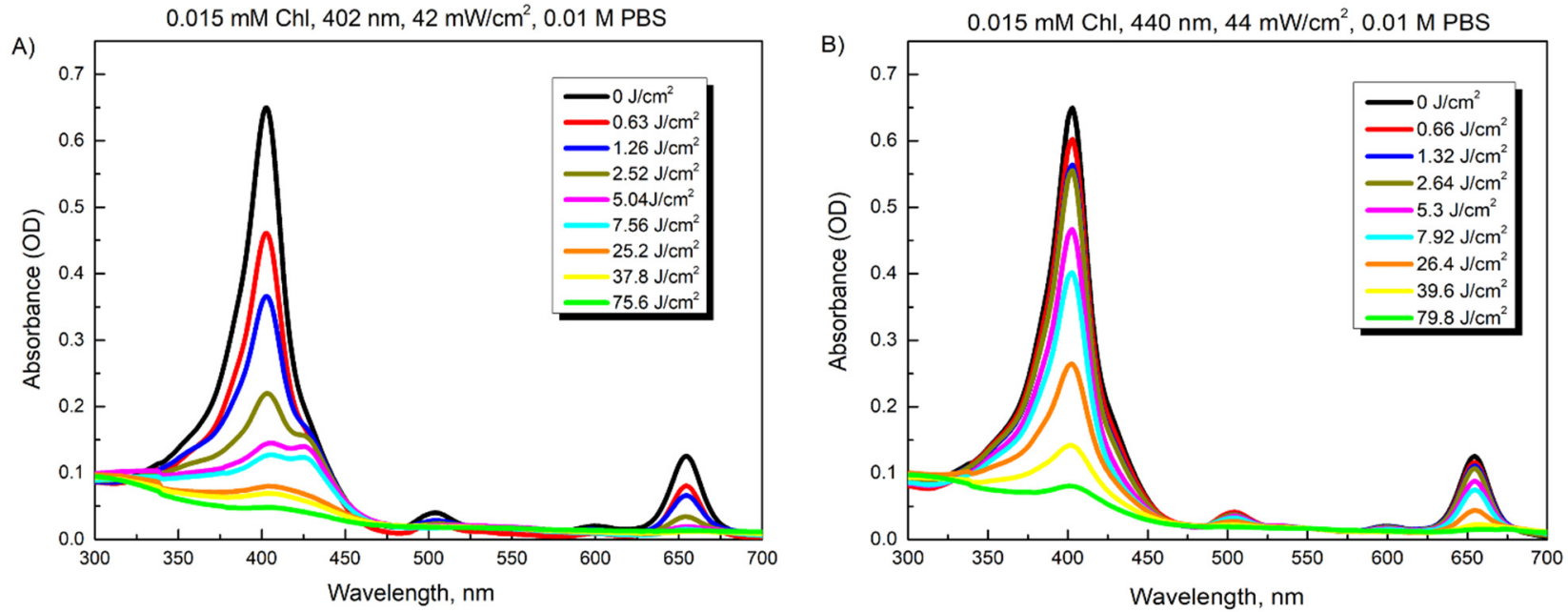

Figure 3. Changes in absorption spectra of $0.015 \mathrm{mM} \mathrm{Chl}$ after increasing illumination with $402 \mathrm{~nm}$ (A) and $440 \mathrm{~nm}$ (B) light. 
Figure 4 illustrates the changes in spectra of the $0.011 \mathrm{mM}$ RF solution after illumination with $440 \mathrm{~nm}\left(44 \mathrm{~mW} / \mathrm{cm}^{2}\right)$ or $402 \mathrm{~nm}$ light $\left(42 \mathrm{~mW} / \mathrm{cm}^{2}\right)$ for various periods $(0-30 \mathrm{~min}$, which correspond to illumination doses of $0-79.8 \mathrm{~J} / \mathrm{cm}^{2}$ ). The absorbance of RF at 373 and $444 \mathrm{~nm}$ decreased unevenly after LED illumination at $440 \mathrm{~nm}$ for $2 \min \left(5.3 \mathrm{~J} / \mathrm{cm}^{2}\right)$ (Figure 4A). Notably, the absorption band at $444 \mathrm{~nm}$ vanished after $10 \mathrm{~min}\left(26.4 \mathrm{~J} / \mathrm{cm}^{2}\right)$. The same decrease in intensity of the main absorption band was observed only after $15 \mathrm{~min}$ of LED illumination at $402 \mathrm{~nm}$. Meanwhile, the absorption changes induced at $373 \mathrm{~nm}$ under these illumination doses showed opposite tendencies for two used LED types. In contrast to Chl photodegradation, these spectroscopic data revealed the photomodification of the RF in buffered solutions at $\mathrm{pH} 7.2$. Thus, after illumination doses of $26.4 \mathrm{~J} / \mathrm{cm}^{2}$ and $37.8 \mathrm{~J} / \mathrm{cm}^{2}$ at $440 \mathrm{~nm}$ or $402 \mathrm{~nm}$, respectively, the main absorption peak at $444 \mathrm{~nm}$ disappeared, while a second peak at $373 \mathrm{~nm}$ transformed into one at $353 \mathrm{~nm}$. Such spectral features imply that the RF underwent phototransformation to a lumichrome photoproduct [34-36].
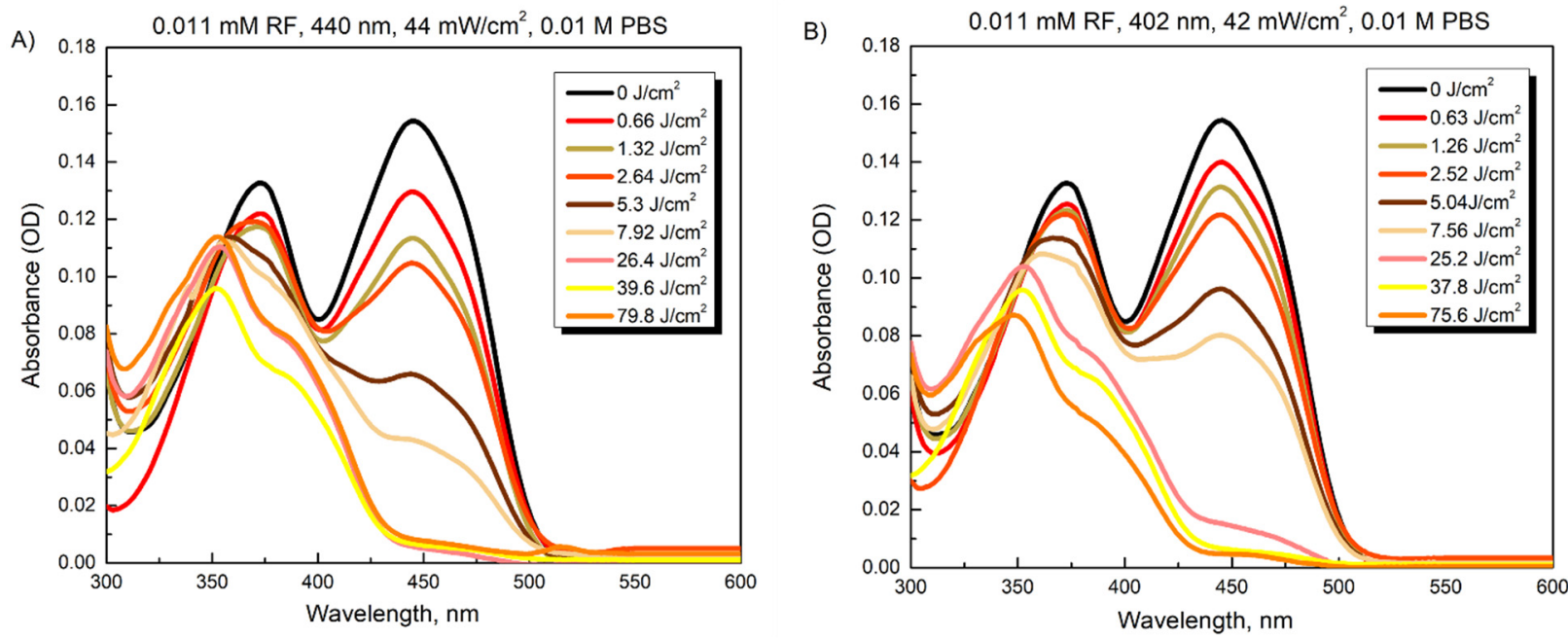

Figure 4. Changes in absorption spectra of $0.011 \mathrm{mM} \mathrm{RF}$ after exposures with $440 \mathrm{~nm}(\mathbf{A})$ and $402 \mathrm{~nm}$ (B) light.

These experiments also allowed us to test the phototransforming efficacy of the light from two different LEDs being applied on both PSs at chosen irradiances in order to set the appropriate conditions for the comparison of the antibacterial activity of $\mathrm{Chl}$ and RF. Based on the obtained photostability data, the highest illumination doses were determined in the case of each light source.

\subsection{Inactivation of Planktonic A. baumannii and S. maltophilia Cells with aPDT}

First, we evaluated the dark toxicity of $\mathrm{Chl}$ and RF on the viability of $A$. baumannii and S. maltophilia. Planktonic bacterial cells were dark-incubated with $0.015 \mathrm{mM}$ of $\mathrm{Chl}$ and $0.011 \mathrm{mM}$ of RF for different time periods, and then viability was assessed as described in the Materials and Methods. As can be seen in Figure 5, incubation with Chl and RF had no impact on A. baumannii and S. maltophilia, viability indicating that the used PSs are nontoxic without irradiation.

Next, the effects of $402 \mathrm{~nm}$ near-UV and $440 \mathrm{~nm}$ blue LED light on the viability of planktonic cells were analyzed. The light alone did not significantly impair A. baumannii viability when the illumination dose was $50.4 \mathrm{~J} / \mathrm{cm}^{2}(402 \mathrm{~nm})$ and $45 \mathrm{~J} / \mathrm{cm}^{2}(440 \mathrm{~nm})$ (Figure 6A). However, a decrease in S. maltophilia viability $\left(1.3 \log _{10}\right)$ was apparent after the same $402 \mathrm{~nm}$ light exposure, indicating the photosensitivity of S. maltophilia SM3 isolate to near-UV light (Figure 6B). 

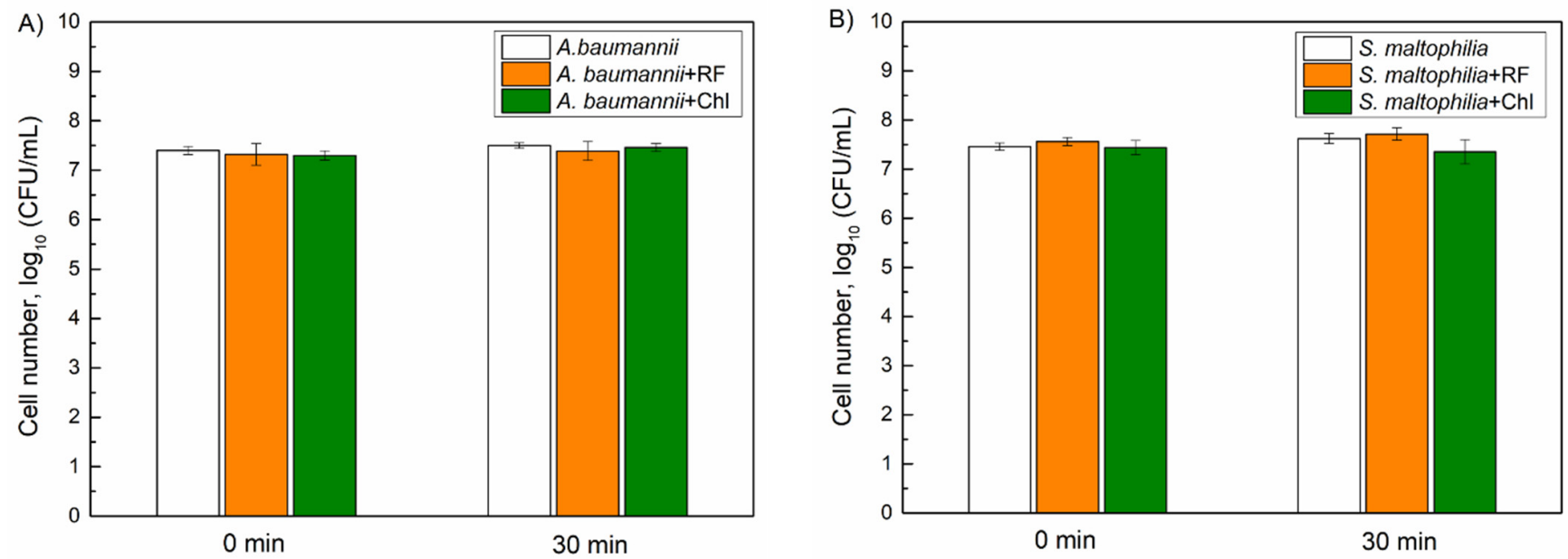

Figure 5. Dark toxicity of $0.015 \mathrm{mM}$ chlorophyllin (Chl) and $0.011 \mathrm{mM}$ riboflavin (RF) on the viability of A. baumannii (A) and S. maltophilia (B) planktonic cells. CFU values present the average of 3-6 experiments, error bars indicate standard deviation.
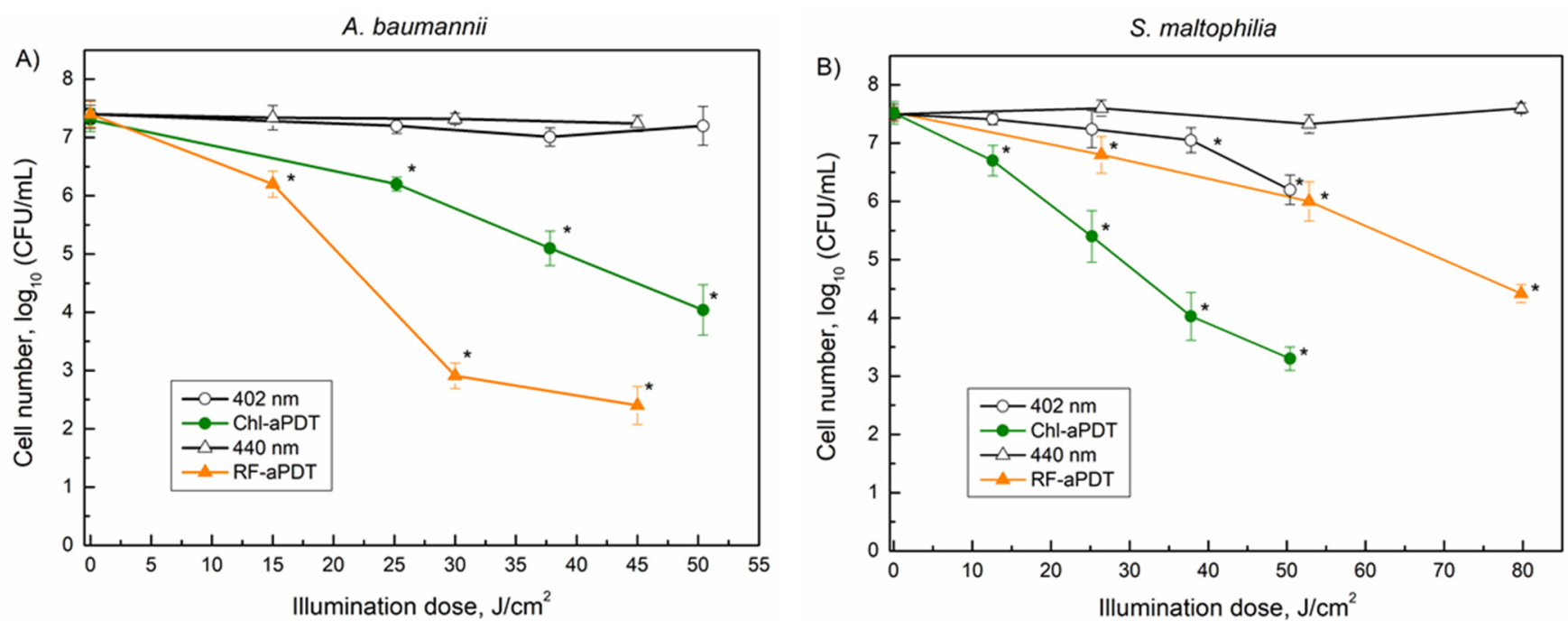

Figure 6. Inactivation of A. baumannii (A) and S. maltophilia (B) planktonic cells by aPDT as function of illumination doses: $402 \mathrm{~nm}$ and Chl-aPDT $(0.015 \mathrm{mM} \mathrm{Chl})$-irradiance $42 \mathrm{~mW} / \mathrm{cm}^{2}(\mathbf{A}, \mathbf{B})$; $440 \mathrm{~nm}$ and RF-aPDT (0.011 mM RF)—irradiance $25 \mathrm{~mW} / \mathrm{cm}^{2}$ (A); $440 \mathrm{~nm}$ and RF-aPDT (0.011 mM $\mathrm{RF}$-irradiance $44 \mathrm{~mW} / \mathrm{cm}^{2}$ (B). Every point is the average of 3-6 experiments, error bars indicate standard deviation. ${ }^{*}$ indicates statistical significance compared to control culture, $p<0.05$.

Next, the aPDT-based inactivation of the planktonic bacterial cells was investigated. The applied illumination doses ranged from 12.6 to $79.8 \mathrm{~J} / \mathrm{cm}^{2}$ using $440 \mathrm{~nm}$ and $402 \mathrm{~nm}$ LED light for the RF and Chl, respectively (Figure 6). The aPDT results showed that A. baumannii was more sensitive to RF-aPDT, which resulted in $5 \log _{10}$ inactivation with the $45 \mathrm{~J} / \mathrm{cm}^{2}$ illumination dose compared to Chl-aPDT, where only $3.4 \log _{10}$ inactivation was observed after similar $50.4 \mathrm{~J} / \mathrm{cm}^{2}$ of illumination (Figure $6 \mathrm{~A}$ ). Conversely, S. maltophilia was more sensitive to Chl-aPDT than to RF-aPDT, resulting in a decrease in CFU by $4.2 \log _{10}$ after illumination with $50.4 \mathrm{~J} / \mathrm{cm}^{2}$, whereas RF-aPDT yielded only a $1.5 \log 10$ decrease in CFU under a similar $52.8 \mathrm{~J} / \mathrm{cm}^{2}$ exposure (Figure $6 \mathrm{~B}$ ). Moreover, the application of a higher illumination dose of $79.8 \mathrm{~J} / \mathrm{cm}^{2}$ in RF-aPDT still resulted in a lower S. maltophilia inactivation $3.1 \log _{10}$ compared to the effect observed for Chl-aPDT with $50.4 \mathrm{~J} / \mathrm{cm}^{2}$ $\left(4.2 \log _{10}\right)$ (Figure 6B). 


\subsection{Inactivation of A. baumannii and S. maltophilia Biofilm Cells with aPDT}

We next investigated the efficiency of the Chl-aPDT and RF-aPDT treatments on A. baumannii and S. maltophilia biofilms (Figure 7). Bacterial biofilms are known to be more resistant to aPDT treatment [37], therefore, for inactivation of A. baumannii, and S. maltophilia biofilms we used 10 times higher PSs concentrations compared to those used for treatment of planktonic cells. In addition, to maximize adsorption of PSs to the biofilms, the microplates with formed biofilms were incubated with PS in the dark at room temperature for $60 \mathrm{~min}$. Incubation with PS only did not affect the viability of biofilm bacteria, similar to the effect observed for planktonic cells of A. baumannii and S. maltophilia (Figure 7). However, light illumination using $440 \mathrm{~nm}\left(158.4 \mathrm{~J} / \mathrm{cm}^{2}\right)$ and $402 \mathrm{~nm}\left(151.2 \mathrm{~J} / \mathrm{cm}^{2}\right)$ significantly reduced cell viability. The $A$. baumannii CFU number decreased by $1.34 \log _{10}$ and $2.94 \log _{10}$ after the $440 \mathrm{~nm}$ and $402 \mathrm{~nm}$ light treatments, respectively. The irradiation effect was even more pronounced for the $S$. maltophilia biofilms, resulting in a reduction of CFU by $1.9 \log _{10}$ after $440 \mathrm{~nm}$ irradiation and by $4 \log _{10}$ after $402 \mathrm{~nm}$ light irradiation.
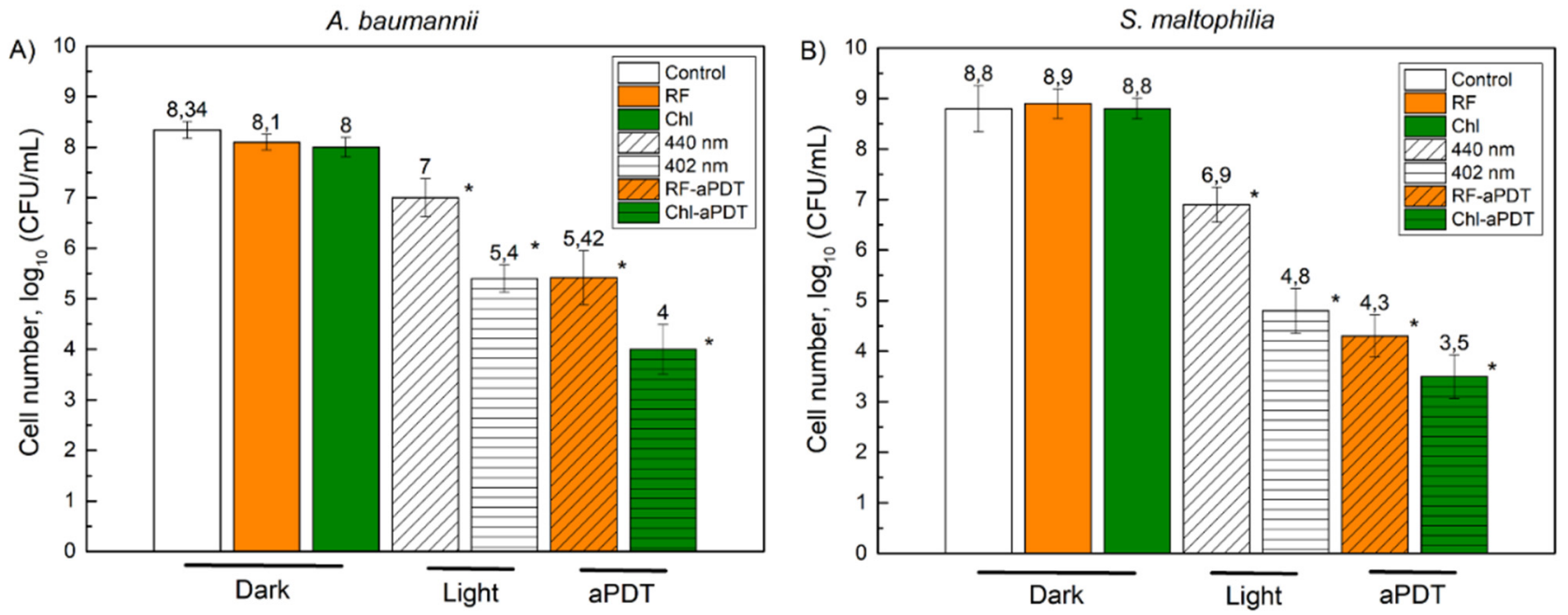

Figure 7. Photodynamic inactivation of A. baumannii (A) and S. maltophilia (B) biofilms using $0.11 \mathrm{mM}$ riboflavin (RF) and $0.15 \mathrm{mM}$ chlorophyllin (Chl) after $60 \mathrm{~min}$ of incubation followed by $60 \mathrm{~min}$ of illumination (440 $\mathrm{nm}$ and RF-aPDT with illumination dose $158.4 \mathrm{~J} / \mathrm{cm}^{2} ; 402 \mathrm{~nm}$ Chl-aPDT, with illumination dose $151.2 \mathrm{~J} / \mathrm{cm}^{2}$ ). The treatment conditions are indicated as dark, light and aPDT. CFU values present the average of 3 experiments, error bars indicate standard deviation. * shows statistical significance compared to the control culture, $p<0.05$. The numbers above the columns are the average of $\log _{10}(\mathrm{CFU} / \mathrm{mL})$.

RF-aPDT and Chl-aPDT resulted in a reduction of $A$. baumannii CFU numbers by $2.92 \log _{10}$ and $4.34 \log _{10}$, respectively (Figure 7A). Interestingly, while planktonic $A$. baumannii cells were more sensitive to RF-aPDT inactivation, biofilm bacteria were more efficiently inactivated by the Chl-aPDT. Treatment of biofilm S. maltophilia with RF-aPDT and Chl-aPDT resulted in a reduction of viable cell numbers by $4.5 \log _{10}\left(158.4 \mathrm{~J} / \mathrm{cm}^{2}\right)$ and $5.3 \log _{10}\left(151.2 \mathrm{~J} / \mathrm{cm}^{2}\right)$, respectively (Figure $\left.7 \mathrm{~B}\right)$.

\section{Discussion}

The emergence of antibiotic resistance amongst nosocomial bacterial infection agents is one of the most pressing worldwide health issues. These infection agents have developed the ability to survive in the hospital environment and gained virulent features required for efficient infection of the host $[18,38]$. The opportunistic pathogens A. baumannii and S. maltophilia are critically important multidrug resistant bacteria which cause severe infections to immunocompromised patients. S. maltophilia and A. baumannii are most frequently obtained from patients with pneumonia and bloodstream infections [39]. S. maltophilia infections are also associated with cystic fibrosis patients [40]. The ability to form biofilms is one of the 
most important virulence factors for both pathogens, and the majority of clinical isolates are biofilm producers [41]. It was shown that S. maltophilia biofilms were up to 128 times more resistant to trimethoprim/sulfamethoxazole and levofloxacin treatment compared with planktonic cells [42]. Biofilm-mediated antibiotic resistance in clinical A. baumannii strains was also described [43]. Therefore, as S. maltophilia and A. baumannii possess multiple resistance mechanisms and a strong capacity to form biofilms, the available options to treat infections caused by these infection agents are limited.

aPDT based on natural photoactive compounds and illumination with 402-440 nm light has the potential to be applied as an antimicrobial technique against antibiotic-resistant planktonic bacteria and biofilms [22]. The main advantages of such an approach are that there is no risk to the patients and the absence of bacterial resistance formation [44]. The interaction of PS and light in the presence of oxygen results in many cytotoxic photooxidative reactions, yielding various ROS [21,23], consequently inducing selective destruction and death of the target bacteria. The antibacterial efficacy of aPDT is influenced by many factors, especially by the physical and chemical properties of the used PSs. However, not all compounds with photosensitizing properties are suitable for aPDT $[45,46]$. The RF and Chl used in this study were selected due to a number of positive and suitable characteristics [22]. RF (or vitamin B2) and Chl are also known as the non-toxic food colorants E-101 and E-140ii, respectively. In addition, they have a status of "Generally Recognized as Safe" (GRAS) and are regarded as not harmful for human consumption [47].

RF is a neutral water-soluble compound that is heat-stable, but quickly degrades under light exposure, especially UV irradiation. RF has three absorption peaks in the UV region (at 223, 267 and $373 \mathrm{~nm}$ ) and one peak at visible region $(444 \mathrm{~nm}$ ) [48,49]. Another relatively new PS used in this study is non-copperrized chlorophyllin sodium salt (Chl) with $\mathrm{Mg}^{2+}$ in the center of the ring. Chl is known as a water-soluble negatively charged (anionic) chlorophyll derivative with a main absorption maximum at $405 \pm 2 \mathrm{~nm}$, that exhibits antimicrobial activity that generates ROS after exposure to visible light $[30,50,51]$. The absorption spectra showed that RF and Chl in PBS solutions (7.4 pH) have main absorption bands at about $402 \mathrm{~nm}$ and $444 \mathrm{~nm}$, respectively. Therefore, an LED-based combined light sourc, emitting at $440 \mathrm{~nm}$ and $402 \mathrm{~nm}$ was used in experiments for the optimal excitation of RF and Chl.

The photostability experiments helped us to assess the RF and Chl photomodifications under the conditions subsequently used to inactivate A. baumannii and S. maltophilia. It is known that during irradiation, RF in aqueous solutions is prone to degradation, resulting in various photoproducts such as formylmethylflavin, lumichrome, lumiflavin, carboxymethylflavin, 2,3-butanedione, a $\beta$-keto acid and a di-keto compound $[48,49,52]$. The types of photoproducts depend on the solvent, $\mathrm{pH}$, buffer type, PS concentration, oxygen content, applied light intensity and spectral region [48]. We showed that irradiation of RF in PBS buffer ( $\mathrm{pH} 7.4$ ), resulted in the disappearance of absorbance peak at $444 \mathrm{~nm}$ and the transformation of $373 \mathrm{~nm}$ peak to $353 \mathrm{~nm}$ (Figure 4). Other studies reported same RF spectral changes under similar conditions (neutral $\mathrm{pH}$ and visible light irradiation) and identified lumichrome as the main RF photodegradation product [34,35,52]. Lumichrome is known to be an efficient PS [53]. Therefore, its photoactivation during RF-aPDT under chosen conditions and its subsequent contribution to bactericidal efficiency cannot be ruled out.

In this study, we demonstrate for the first time that RF and Chl-based aPDT inactivate the opportunistic pathogens A. baumannii and S. maltophilia and their biofilms. We found that $A$. baumannii planctonic cells were highly susceptible to RF-aPDT treatment using a $0.01 \mathrm{mM}$ RF concentration, yielding a reduction of viable bacteria by $5 \log _{10}$ after exposition with $45 \mathrm{~J} / \mathrm{cm}^{2}$. Maish et al. [28] showed that the positively charged RF derivatives FLASH-01a and FLASH-07a $(0.01 \mathrm{mM})$, irradiated with $9 \mathrm{~J} / \mathrm{cm}^{2}$ and $3 \mathrm{~J} / \mathrm{cm}^{2}$ expositions $\left(50 \mathrm{~mW} / \mathrm{cm}^{2}\right)$, reduced $A$. baumannii CFU by $5.7 \log _{10}$ and $5.8 \log _{10}$ using source emitting non-coherent 380-600 nm light. Another natural PS, Aloe emodin, after irradiation of $0.1 \mathrm{mM}$ PS solution with $435 \mathrm{~nm} \pm 10 \mathrm{~nm}\left(80 \mathrm{~mW} / \mathrm{cm}^{2}\right)$ at a $96 \mathrm{~J} / \mathrm{cm}^{2}$ illumination 
dose, reduced the CFU of clinical $A$. baumannii from 4.5 to $6.89 \log _{10}$, depending on the bacterial isolate [25]. The A. baumannii inactivation efficiency shown for RF-aPDT in our study, is similar to that reported for Aloe emodin, although the former was achieved applying a ten-times higher dye concentration and a twice-higher illumination dose. Chang et al. [26] reported $97.5 \%$ inhibition of imipenem-resistant $A$. baumannii planktonic cells with curcumin-based aPDT. The effect was achieved by applying a $0.2 \mathrm{mM}$ PS concentration and blue light irradiation using a $5.4 \mathrm{~J} / \mathrm{cm}^{2}$ illumination dose $\left(3 \mathrm{~mW} / \mathrm{cm}^{2}\right)$. aPDT using $1.25 \mathrm{mM}$ 5-ALA, a precursor of PS protoporphyrin IX, reduced the number of viable $A$. baumannii planktonic cells by $2.95 \log _{10}$ only after $4 \mathrm{~h}$ preincubation with 5 -ALA, followed by $402 \mathrm{~nm}$ blue light irradiation with $23.4 \mathrm{~J} / \mathrm{cm}^{2}$ illumination dose [27].

The literature review showed that there are no studies analyzing inactivation of A. baumannii biofilms with natural PS-based aPDT. Z. Fekrirad et al. [54] analyzed the inactivation of biofilms formed by two clinical $A$. baumannii isolates by applying aPDT mediated by anionic PS erythrosine B, although only $0.1 \mathrm{mM}$ erythrosine B complex with chitosan $(12.5 \mathrm{mg} / \mathrm{mL})$ and acetic acid $(0.01 \%)$ with an $80 \mathrm{~J} / \mathrm{cm}^{2}$ illumination dose resulted in $>3 \log _{10}$ reduction of biofilm bacteria. In our study, anionic $\mathrm{Chl}$ alone caused a $>4 \log _{10}$ reduction of $A$. baumannii biofilm bacteria, albeit by applying a two-times higher illumination dose with a $402 \mathrm{~nm}$ LED light (Figure 7A).

To the best of our knowledge, there is no published data about aPDT-caused inactivation of S. maltophilia pathogen. While planktonic S. maltophilia cells were more sensitive to Chl-aPTD compared to RF-aPDT (Figure 6B), the inactivation of biofilms using RF-aPDT and Chl-aPDT produced similar results of $4.5 \log _{10}$ and $5.3 \log _{10}$, respectively (Figure 7B). On the contrary, while $A$. baumannii planktonic cells were more sensitive to RF-aPDT (Figure 6A), the biofilm bacteria were more susceptible to Chl-aPDT, similarly to the inactivation of $S$. maltophilia biofilms. Interestingly, $402 \mathrm{~nm}$ near-UV light alone significantly reduced the viability of biofilm cells, for instance the $S$. maltophilia inactivation efficiency using $402 \mathrm{~nm}$ light was close to that of RF-aPDT (440 nm light) under similar illumination dose. According to our observations, more than a two-times higher illumination dose and ten-times higher PS concentrations are required to achieve the inactivation effect on A. baumannii and S. maltophilia biofilm cells, comparable to that observed for planktonic cells. Compared to RF-aPDT, Chl-aPDT has a stronger inactivation effect on biofilms of both $A$. baumannii and $S$. maltophilia, while for the planktonic cells, the inactivation results were different. A. baumannii was more sensitive to RF-aPDT while S. maltophilia was more sensitive to Chl-aPTD. RF-aPDT and Chl-aPDT may be an optional antimicrobial method for control of these pathogens.

In summary, all the analyzed results suggest that RF-aPDT and Chl-aPDT can be used as a potential antimicrobial treatment for A. baumannii and S. maltophilia inactivation, both for planktonic and biofilm cells. Biofilm cells of both pathogens were more susceptible to near-UV light, indicating that Chl-aPDT with $402 \mathrm{~nm}$ LED light illumination is more suitable to inactivate A. baumannii and S. maltophilia biofilms.

Author Contributions: I.B., E.S. and S.B. conceived and designed the experiments; I.B. performed the experiments; I.B., L.K., E.S. and S.B. analyzed the data; I.B. and L.K. wrote the paper. All authors have read and agreed to the published version of the manuscript.

Funding: This research was funded by the European Social Fund under the No 09.3.3-LMT-K-712 "Development of Competences of Scientist, other Researchers and Students through Practical Research Activities" measure.

Institutional Review Board Statement: Not applicable.

Informed Consent Statement: Not applicable.

Conflicts of Interest: The authors declare no conflict of interest. 


\section{References}

1. European Centre for Disease Prevention and Control. Antimicrobial Resistance Surveillance in Europe 2016. Available online: https:/ / www.ecdc.europa.eu/en/publications-data/antimicrobial-resistance-surveillance-europe-2016 (accessed on 30 December 2021).

2. Rice, L.B. Federal Funding for the Study of Antimicrobial Resistance in Nosocomial Pathogens: No ESKAPE. J. Infect. Dis. 2008, 197, 1079-1081. [CrossRef]

3. Monegro, A.F.; Muppidi, V.; Regunath, H. Hospital Acquired Infections. In StatPearls [Internet]; StatPearls Publishing: Treasure Island, FL, USA, 2021. [PubMed]

4. Cassini, A.; Högberg, L.D.; Plachouras, D.; Quattrocchi, A.; Hoxha, A.; Simonsen, G.S.; Colomb-Cotinat, M.; Kretzschmar, M.E.; Devleesschauwer, B.; Cecchini, M.; et al. Attributable deaths and disability-adjusted life-years caused by infections with antibioticresistant bacteria in the EU and the European Economic Area in 2015: A population-level modelling analysis. Lancet Infect. Dis. 2019, 19, 56-66. [CrossRef]

5. $\quad$ Chuang, Y.-C.; Sheng, W.-H.; Li, S.-Y.; Lin, Y.-C.; Wang, J.-T.; Chen, Y.-C.; Chang, S.-C. Influence of Genospecies of Acinetobacter baumannii Complex on Clinical Outcomes of Patients with Acinetobacter Bacteremia. Clin. Infect. Dis. 2010, 52, 352-360. [CrossRef]

6. Eveillard, M.; Kempf, M.; Belmonte, O.; Pailhoriès, H.; Joly-Guillou, M.-L. Reservoirs of Acinetobacter baumannii outside the hos-pital and potential involvement in emerging human community-acquired infections. Int. J. Infect. Dis 2013, 17, e802-e805. [CrossRef]

7. Karakonstantis, S.; Kritsotakis, E.I.; Gikas, A. Treatment options for K. pneumoniae, P. aeruginosa and A. baumannii co-resistant to carbapenems, aminoglycosides, polymyxins and tigecycline: An approach based on the mechanisms of resistance to car-bapenems. Infection 2020, 48, 835-851. [CrossRef]

8. Suetens, C.; Latour, K.; Kärki, T.; Ricchizzi, E.; Kinross, P.; Moro, M.L.; Jans, B.; Hopkins, S.; Hansen, S.; Lyytikäinen, O.; et al. Prevalence of healthcare-associated infections, estimated incidence and composite antimicrobial resistance index in acute care hospitals and long-term care facilities: Results from two European point prevalence surveys, 2016 to 2017. Eurosurveillance 2018, 23, 1800516. [CrossRef]

9. Singhal, L.; Kaur, P.; Gautam, V. Stenotrophomonas maltophilia: From Trivial to Grievous. Indian J. Med. Microbiol. 2017, 35, 469-479. [CrossRef]

10. Pompilio, A.; Crocetta, V.; Confalone, P.; Nicoletti, M.; Petrucca, A.; Guarnieri, S.; Fiscarelli, E.; Savini, V.; Piccolomini, R.; Di Bonaventura, G. Adhesion to and biofilm formation on IB3-1 bronchial cells by Stenotrophomonas maltophilia isolates from cystic fibrosis patients. BMC Microbiol. 2010, 10, 102. [CrossRef]

11. Brooke, J.S. New strategies against Stenotrophomonas maltophilia: A serious worldwide intrinsically drug-resistant opportun-istic pathogen. Expert Rev. Anti. Infect. Ther. 2014, 12, 1-4. [CrossRef]

12. Chang, Y.-T.; Lin, C.-Y.; Chen, Y.-H.; Hsueh, P.-R. Update on infections caused by Stenotrophomonas maltophilia with particular attention to resistance mechanisms and therapeutic options. Front. Microbiol. 2015, 6, 893. [CrossRef]

13. Trifonova, A.; Strateva, T. Stenotrophomonas maltophilia—a low-grade pathogen with numerous virulence factors. Infect. Dis. 2018, 51, 168-178. [CrossRef]

14. Sánchez, M.B. Antibiotic resistance in the opportunistic pathogen Stenotrophomonas maltophilia. Front. Microbiol. 2015, 6, 658. [CrossRef]

15. Gibb, J.; Wong, D.W. Antimicrobial Treatment Strategies for Stenotrophomonas maltophilia: A Focus on Novel Therapies. Antibiotics 2021, 10, 1226. [CrossRef]

16. Høiby, N. A short history of microbial biofilms and biofilm infections. APMIS 2017, 125, 272-275. [CrossRef]

17. Satpathy, S.; Sen, S.K.; Pattanaik, S.; Raut, S. Review on bacterial biofilm: An universal cause of contamination. Biocatal. Agric. Biotechnol. 2016, 7, 56-66. [CrossRef]

18. Lin, M.-F.; Lan, C.-Y. Antimicrobial resistance in Acinetobacter baumannii: From bench to bedside. World J. Clin. Cases 2014, 2, 787-814. [CrossRef]

19. Galiè, S.; García-Gutiérrez, C.; Miguélez, E.M.; Villar, C.J.; Lombó, F. Biofilms in the Food Industry: Health Aspects and Control Methods. Front. Microbiol. 2018, 9, 898. [CrossRef]

20. Wainwright, M. Photodynamic antimicrobial chemotherapy (PACT). J. Antimicrob. Chemother. 1998, 42, 13-28. [CrossRef]

21. St Denis, T.G.; Hamblin, M.R. An Introduction to Photoantimicrobials: Photodynamic Therapy as a Novel Method of Microbial Pathogen Eradication. In Science against Microbial Pathogens: Communicating Current Research and Technological Advances; Méndez-Vilas, A., Ed.; Formatex Research Center: Badajoz, Spain, 2011; pp. 675-683.

22. Buchovec, I.; Gricajeva, A.; Kalèdienè, L.; Vitta, P. Antimicrobial Photoinactivation Approach Based on Natural Agents for Control of Bacteria Biofilms in Spacecraft. Int. J. Mol. Sci. 2020, 21, 6932. [CrossRef]

23. Wainwright, M.; Maisch, T.; Nonell, S.; Plaetzer, K.; Almeida, A.; Tegos, G.P.; Hamblin, M.R. Photoantimicrobials—Are we afraid of the light? Lancet Infect. Dis. 2017, 17, e49-e55. [CrossRef]

24. Ghorbani, J.; Rahban, D.; Aghamiri, S.; Teymouri, A.; Bahador, A. Photosensitizers in antibacterial photodynamic therapy: An overview. Laser Ther. 2018, 27, 293-302. [CrossRef] 
25. Li, J.; Qin, M.; Liu, C.; Ma, W.; Zeng, X.; Ji, Y. Antimicrobial photodynamic therapy against multidrug-resistant Acinetobacter bau-mannii clinical isolates mediated by aloe-emodin: An in vitro study. Photodiagnosis Photodyn. Ther. 2020, $29,101632$. [CrossRef]

26. Chang, K.; Cheng, Y.; Lai, M.; Hu, A. Identification of carbonylated proteins in a bactericidal process induced by curcumin with blue light irradiation on imipenem-resistant Acinetobacter baumannii. Rapid Commun. Mass Spectrom. 2019, 34, e8548. [CrossRef]

27. Maliszewska, I.; Goldeman, W. Pentamidine enhances photosensitization of Acinetobacter baumannii using diode lasers with emission of light at wavelength of $\Lambda=405 \mathrm{~nm}$ and $\Lambda=635 \mathrm{~nm}$. Photodiagnosis Photodyn. Ther. 2021, 34, 102242. [CrossRef]

28. Maisch, T.; Eichner, A.; Späth, A.; Gollmer, A.; Koenig, B.; Regensburger, J.; Bäumler, W. Fast and Effective Photodynamic Inactivation of Multiresistant Bacteria by Cationic Riboflavin Derivatives. PLoS ONE 2014, 9, e111792. [CrossRef]

29. Mazzotta, C.; Caragiuli, S.; Caporossi, A. Riboflavin and the Cornea and Implications for Cataracts. In Handbook of Nutrition, Diet and the Eye; Academic Press: London, UK, 2014; pp. 123-130.

30. Buchovec, I.; Lukseviciūte, V.; Kokstaite, R.; Labeikyte, D.; Kaziukonyte, L.; Luksiene, Z. Inactivation of Gram (-) bacteria Salmonella enterica by chlorophyllin-based photosensitization: Mechanism of action and new strategies to enhance the inactivation efficiency. J. Photochem. Photobiol. B 2017, 172, 1-10. [CrossRef]

31. Skerniškytė, J.; Krasauskas, R.; Péchoux, C.; Kulakauskas, S.; Armalytė, J.; Sužiedèlienė, E. Surface-Related Features and Virulence Among Acinetobacter baumannii Clinical Isolates Belonging to International Clones I and II. Front. Microbiol. $2019,9,3116$. [CrossRef]

32. Klimkaitè, L.; Armalytè, J.; Skerniškytè, J.; Sužiedèlienè, E. The Toxin-Antitoxin Systems of the Opportunistic Pathogen Stenotrophomonas maltophilia of Environmental and Clinical Origin. Toxins 2020, 12, 635. [CrossRef]

33. Naghili, H.; Tajik, H.; Mardani, K.; Razavi Rouhani, S.M.; Ehsani, A.; Zare, P. Validation of drop plate technique for bacterial enumeration by parametric and nonparametric tests. Vet. Res. Forum 2013, 4, 179-183.

34. Ahmad, I.; Fasihullah, Q.; Vaid, F.H.M. Effect of phosphate buffer on photodegradation reactions of riboflavin in aqueous solu-tion. J Photochem. Photobiol. B 2005, 78, 229-234. [CrossRef]

35. Ahmad, I.; Fasihullah, Q.; Vaid, F.H.M. Effect of light intensity and wavelengths on photodegradation reactions of riboflavin in aqueous solution. J. Photochem. Photobiol. B 2006, 82, 21-27. [CrossRef]

36. Ahmad, I.; Fasihullah, Q.; Vaid, F.H.M. A study of simultaneous photolysis and photoaddition reactions of riboflavin in aqueous solution. J. Photochem. Photobiol. B 2004, 75, 13-20. [CrossRef]

37. Hu, X.; Huang, Y.-Y.; Wang, Y.; Wang, X.; Hamblin, M.R. Antimicrobial Photodynamic Therapy to Control Clinically Relevant Bio-film Infections. Front. Microbiol. 2018, 9, 1299. [CrossRef]

38. Looney, W.J.; Narita, M.; Mühlemann, K. Stenotrophomonas maltophilia: An emerging opportunist human pathogen. Lancet Infect. Dis. 2009, 9, 312-323. [CrossRef]

39. Gales, A.C.; Seifert, H.; Gur, D.; Castanheira, M.; Jones, R.N.; Sader, H.S. Antimicrobial Susceptibility of Acinetobacter calcoaceticus-Acinetobacter baumannii Complex and Stenotrophomonas maltophilia Clinical Isolates: Results From the SENTRY Antimicrobial Surveillance Program (1997-2016). Open Forum Infect. Dis. 2019, 6, S34-S46. [CrossRef]

40. Waters, V.; Yau, Y.; Prasad, S.; Lu, A.; Atenafu, E.; Crandall, I.; Tom, S.; Tullis, E.; Ratjen, F. Stenotrophomonas maltophilia in cystic fibrosis: Serologic re-sponse and effect on lung disease. Am. J. Respir. Crit. Care Med. 2011, 183, 635-640. [CrossRef]

41. Di Bonaventura, G.; Spedicato, I.; D'Antonio, D.; Robuffo, I.; Piccolomini, R. Biofilm formation by Stenotrophomonas maltophilia: Modulation by quinolones, trimethoprim-sulfamethoxazole, and ceftazidime. Antimicrob. Agents Chemother. 2004, 48, 151-160. [CrossRef]

42. Pompilio, A.; Ranalli, M.; Piccirilli, A.; Perilli, M.; Vukovic, D.; Savic, B.; Krutova, M.; Drevinek, P.; Jonas, D.; Fiscarelli, E.V.; et al Biofilm Formation among Stenotrophomonas maltophilia Isolates Has Clinical Relevance: The ANSELM Prospective Multicenter Study. Microorganisms 2021, 9, 49. [CrossRef]

43. Shenkutie, A.M.; Yao, M.Z.; Siu, G.K.-H.; Wong, B.K.C.; Leung, P.H.-M. Biofilm-Induced Antibiotic Resistance in Clinical Acinetobacter baumannii Isolates. Antibiotics 2020, 9, 817. [CrossRef]

44. Liu, Y.; Qin, R.; Zaat, S.A.J.; Breukink, E.; Heger, M. Antibacterial photodynamic therapy: Overview of a promising approach to fight antibiotic-resistant bacterial infections. J. Clin. Transl. Res. 2015, 1, 140-167.

45. Klausen, M.; Ucuncu, M.; Bradley, M. Design of Photosensitizing Agents for Targeted Antimicrobial Photodynamic Therapy. Molecules 2020, 25, 5239. [CrossRef] [PubMed]

46. Yin, R.; Hamblin, M. Antimicrobial Photosensitizers: Drug Discovery Under the Spotlight. Curr. Med. Chem. 2015, 22, 2159-2185. [CrossRef] [PubMed]

47. CFR—Code of Federal Regulations Title 21. Available online: https://www.accessdata.fda.gov/scripts/cdrh/cfdocs/cfcfr/ CFRSearch.cfm?fr=184.1695 (accessed on 30 December 2021).

48. Sheraz, M.A.; Kazi, S.H.; Ahmed, S.; Anwar, Z.; Ahmad, I. Photo, thermal and chemical degradation of riboflavin. Beilstein J. Org. Chem. 2014, 10, 1999-2012. [CrossRef] [PubMed]

49. Astanov, S.; Sharipov, M.Z.; Fayzullaev, A.R.; Kurtaliev, E.N.; Nizomov, N. Spectroscopic study of photo and thermal destruction of riboflavin. J. Mol. Struct. 2014, 1071, 133-138. [CrossRef]

50. Buchovec, I.; Lukseviciute, V.; Marsalka, A.; Reklaitis, I.; Luksiene, Z. Effective photosensitization-based inactivation of Gram (-) food pathogens and molds using the chlorophyllin-chitosan complex: Towards photoactive edible coatings to preserve strawberries. Photochem. Photobiol. Sci. 2016, 15, 506-516. [CrossRef] 
51. Žudytè, B.; Velička, M.; Šablinskas, V.; Lukšienė, Ž. Understanding Escherichia coli damages after chlorophyllin-based photosensitization. J. Biophotonics 2020, 13, e202000144. [CrossRef]

52. Kim, E.; Kim, M.H.; Song, J.H.; Kang, C.; Park, W.H. Dual crosslinked alginate hydrogels by riboflavin as photoinitiator. Int. J. Biol. Macromol. 2020, 154, 989-998. [CrossRef]

53. Bergh, V.J.V.; Tønnesen, H.H. Interaction between the photosensitizer lumichrome and human serum albumin: Effect of excipients. Pharm. Dev. Technol. 2017, 22, 992-1000. [CrossRef]

54. Fekrirad, Z.; Darabpour, E.; Kashef, N. Eradication of Acinetobacter baumannii Planktonic and Biofilm Cells Through Erythrosine-Mediated Photodynamic Inactivation Augmented by Acetic Acid and Chitosan. Curr. Microbiol. 2021, 78, 879-886. 